\title{
PLACE NAMES AND IDENTITIES
}

\author{
BOTOLV HELLELAND \\ University of Oslo
}

ABS TRACT

This paper discusses various approaches to the topic "place names and identities", addressing the meaning of place names, their role as links to the past as well as their identity-building capacity. The author argues that there is an intimate relationship between place and place name, and he discusses how place names may reflect or give rise to feelings of individual and collective identity attached to the places in question. Three particular personal experiences of the identity role of place names are given, two at the beginning of the paper and one in the conclusion.

\section{[1] INTRODUCTION}

Some time ago when travelling by train from Oslo to Bergen I happened to sit next to a charming elderly lady. As often happens during a long journey we started a conversation, and after having agreed upon the pleasure of a relaxing railway trip through a varied landscape we started to talk about names. Born and still living in Bergen, my travel companion expressed her strong ties to Frammarsvik ${ }^{1}$, a farm and village in Førde in Western Norway. It turned out that her father was born there and had kept the farm name as surname, which is a very common practice in Norway. Frammarsvik had also been her surname before she married. When asked about her relationship to the village of Frammarsvik she said that she used to spend the holidays with her parents in this place. The name of Frammarsvik identified a very particular place to her, at the same time as the name itself was a part of her identity. To her, Frammarsvik represented the dearest place in the world, a name which opened up a world of memories and experiences, of people, of joy as well as sorrow. These feelings were becoming more distinct as she grew older, she admitted. Obviously this incident is not unique when it comes to the identifying and identity function of a name. Recently I met a married couple of about 50 years, and when we touched upon the topic "roots" and our joint West Norwegian background, the woman exclaimed: "We have a hut in Reinsnos and have spent many of our holidays there for 25 years. The place is part of our identity and means a lot to us." When I asked what first came into her mind when

[1] The first element of Frammarsvik is possibly a male name Old Norse Framarr, whereas the last element is vik "bay, inlet" (Rygh 1919, 334); for a detailed map presentation search in http: //www . norgeskart. no/adaptive2/default . aspx?gui=1\&lang=2. 
thinking of the hut, the place or the name, she said "both, simultaneously, they are interrelated". The identity role of a place name may even be demonstrated by a slogan, like the one I noticed some years ago on the T-shirt of a young woman from Botswana: "Serowe is home".

In this article I will discuss some aspects relating to the double notion of "place names and identities". Although name research is considered primarily a linguistic discipline, it is associated with a number of other research fields, like cognitive linguistics, anthropology and history, to mention a few more. The topic place names and identities also calls for a number of approaches, but the limited space here does not allow me to go into this in depth. However, as we will see, several of the other contributors to this volume have treated the topic from various angles. Some of the key terms to be dealt with from my point of view are meaning, historical and social value, identity, place name, space and place, name attachment and place attachment.

Anthropologists in particular have investigated the role of place names as references to and symbols of acts and experiences both in tribal and Western contexts. As stated above, place names are social signals of belonging to a group, and the more names that are shared, the stronger the bonds are within the group. In recent years there has been an increasing interest among onomasticians to deal with the identity aspect of place names, partly inspired by the achievements of anthropologists and geographers.

Most people would agree that it is fundamental for the wellbeing of individuals to be familiar with places and place names in their surroundings in the same way as it means a lot to have close relationships to one's family and neighbours. To know the places and the names of the places in one's neighbourhood is part of the spirit of community. The names and their stories "create the spirit of the place, its 'genius loci”' (Viljamaa-Laakso 1998, 364). In their capacity as synchronic and diachronic expressions attached to smaller or bigger places, place names are a vital part of everyday language as well as of the individual and collective memory and collective identity (Eskeland 2001). The Finnish name scholar and poet Lars Huldén puts it like this (my translation):

Name and place belong together, regardless of how the name is formed etymologically. The name is a key to memories and experiences. To be familiar with the same name is to know a little about each other. Names are social signals of solidarity. The more names one shares with others, the stronger the solidarity with them is ${ }^{2}$ (Huldén 1994, 33).

[2] "Namn och plats hör ihop, oberoende av hur namnen etymologiskt sett är bildade. Namnet är en nyckel till minnen och upplevda intryck. Att känna samma namn är detsamma som att veta lite om varandra. Namnen är en social signal för samhörighet. Ju fler namn man delar med någon, dess större är samhörigheten." 


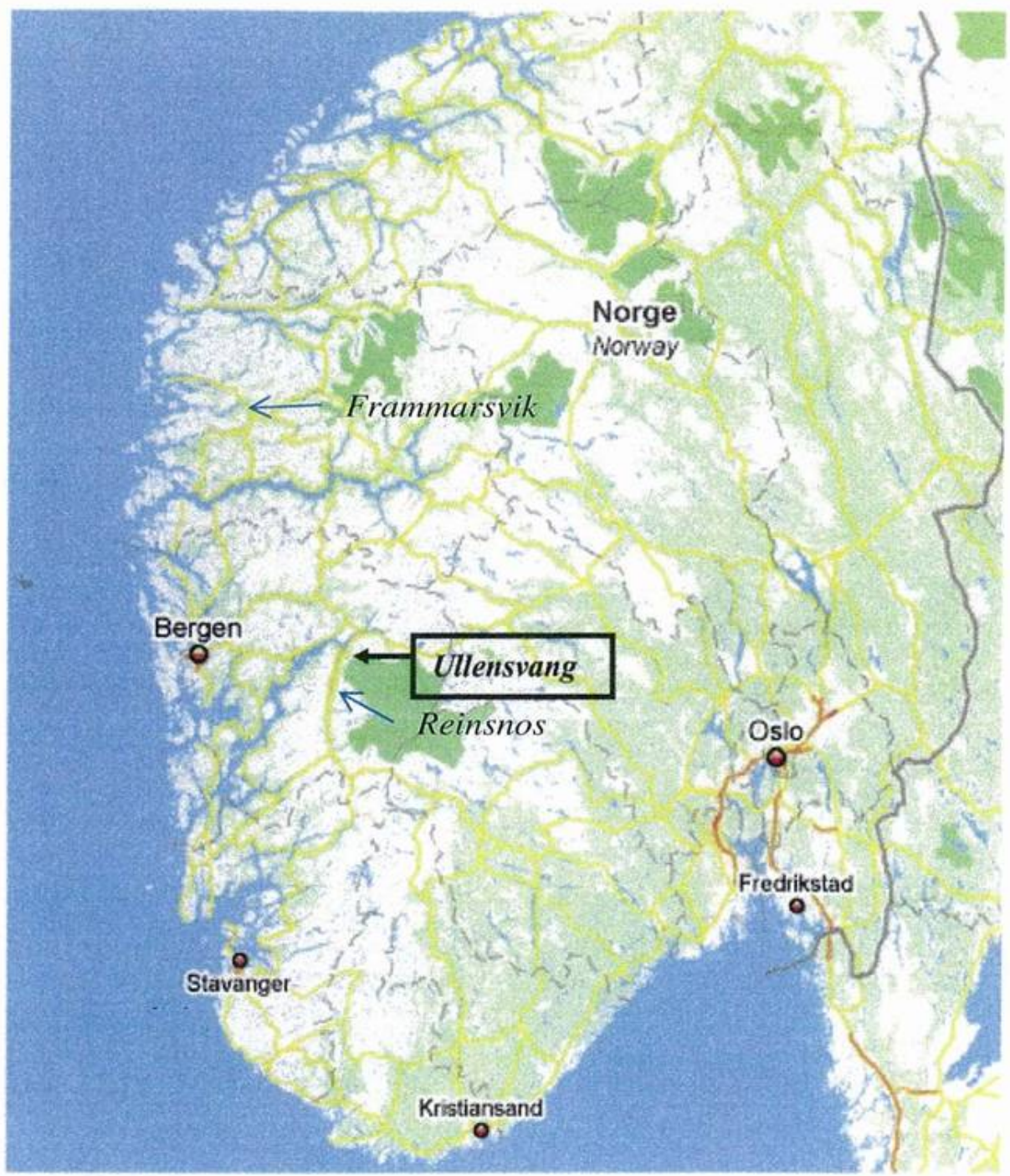

FIGURE 1: Map of southern Norway. The names Frammarsvik, Reinsnos and Ullensvang which are referred to in the text are marked on the map. 
It is also a trait of human mentality that place names should be consistent and permanent. When it is proposed to substitute a place name with another name, or even only to change its spelling, people may react with discontent and sometimes anger. And when a street, a park or another public area is to be named, intense discussions may arise. In fact, settlement planners are to an increasing extent preoccupied with the identity role of place names. Thus it is mentioned in the plans for a park area in Copenhagen some years ago that "Nørrebropark lends name and identity to the whole quarter."3 (Holmgren 2005) Domain names on the Internet are attributed much attention in terms of identity too, with firms for instance valuing the maintenance of a consistent domain name identity instead of perhaps introducing a more "fancy" name (Zook 2000).

Place names play an important role on a regional and national level too, and name changes may create strong feelings among large groups of people, especially in multi-ethnic areas. For example, during the $20^{\text {th }}$ century a number of ideologically motivated name conflicts arose as a consequence of warfare and occupation (Lietz (2009), see also Radić in this volume). In Arseny Saparov's words, place names are "some of the most durable of national symbols ... [They] are important features of national and territorial identity" (Saparov 2003, 179). Duncan Light (Light 2004) posits that names which commemorate important events or personalities from a country's history can be significant expressions of national identity with powerful symbolic importance. In 1924, when the former name of the Norwegian capital Kristiania was changed back to its medieval name Oslo, there was quite a struggle (Wetås 2000, $34 \mathrm{ff}$.), and even more so when the parliament voted in 1929 to replace Trondhjem with the medieval name Nidaros. The subsequent struggle forced the parliament to a withdraw its resolution and, in 1931, Trondheim was agreed to as a compromise name. Today the names of Oslo and Trondheim are generally accepted and looked upon as icons of those cities.

The relationship between names and identity, here more precisely place names and identity, is a complex subject which has been discussed from many viewpoints within various disciplines. It is often argued that names, especially place names, are not only a source of linguistic knowledge, but also of geographical, historical, anthropological, ethnographic, social, psychological, and other knowledge and may be of interest to these respective sciences. In their turn, name scholars may take advantage of data from a broad range of sciences when dealing with names. There are numerous examples demonstrating the value of such interdisciplinary approaches (e.g. Gelling (1990), Helleland (1990)). When applying onomastics in geographical studies we must take into account that we are dealing with fundamentally different levels on which "landscape", or more precisely "place", and "place name" occur. The former may be examined and described as a measurable

[3] "Nørrebropark giver navn og identitet til hele kvarteret". 
physical entity, whereas the latter consists of a linguistic expression and as such is an abstraction of the named object. Nevertheless there is an intimate relationship between place and place name, and I will discuss below how place names may reflect or give rise to feelings of individual and collective identity attached to the places in question.

\section{[2] FUNCTION AND MEANING OF PLACE NAMES}

Place names, like other names, are an indispensable part of human language. We use names when we refer to individual objects, such as people, animals, buildings, organisations, artefacts and places. Names are used in a variety of functions, not only as expressions referring to particular objects but also as a way of communicating cognitively, emotionally, ideologically, and socially (Andersson 1994, 8). Within toponymic research the etymological discussion and the historical bearings of place names have traditionally attracted the widest interest among scholars, especially in Europe. The main focus was placed on the linguistic structure and the semantic identification and grouping of various elements. Besides, it was seen as important to dismantle the meaning of names in order to use place name material as a historical source, especially for settlement history but also in the study of a wide range of natural and cultural phenomena that are reflected in place names (Christensen \& Sørensen 1972; Ziegler \& Windberger-Heidenkummer 2011). This kind of name studies is still on the agenda, but over the last few decades there has been a noticeable shift in onomastic interest with increasing focus on the socio-onomastic and socio-psychological functions of place names and other names.

Naturally, the terms "meaning" and "sense" have been discussed ardently in the course of the debates on theoretical onomastics. One of the great issues regarding the content and function of a name is whether it has a "meaning" or "sense" beyond its reference. This question is also relevant when it comes to the identity aspect of a name. It is not my intention here to retrace the extensive discussion of name and meaning; for a survey, see Willy Van Langendonck's book on this topic (Van Langendonck 2007). I will confine myself to making a few comments pertaining to the two main approaches to the question:

- a name has reference, but is empty of meaning

- a name is "brimful" of (connotative) meaning

It is well known that philosophers like John Stuart Mill (Mill 1884) and, in more recent times, Bertrand Russell (Russell 1940) and Sir Alan Gardiner (Gardiner 1954) maintained that names have reference, but are empty of meaning. The latter's often quoted claim "the purest of proper names are wholly arbitrary and totally without significance" (Gardiner 1954,19) has been contested by many 
other scholars, for instance Gottlob Frege (Frege 1962), who claims that there is much more to the meaning of a name than simply the object to which it refers. John R. Searle, who does not agree with Frege on all theoretical aspects, comments upon the role of proper names in the following way:

But the uniqueness and immense pragmatic convenience of proper names in our language lies precisely in the fact that they enable us to refer publicly to objects without being forced to raise issues and come to an agreement as to which descriptive characteristics exactly constitute the identity of the object. They function not as descriptions, but as pegs on which to hang descriptions (Searle 1969, 172).

Similar positions are advocated by scholars like Otto Jespersen and Holger Steen Sørensen. The German scholar Klaus Hilgemann notes that a name through its connotations and associations acquires an extended meaning, maintaining that:

Die Größe der Information [eines Namens] richtet sich nach der Bekanntheit des Trägers und nach dem Grad des Bekanntseins mit dem [Namens]Träger. Die Bedeutung eines Namens ist für jeden Sprecher/Hörer verschieden ... (Hilgemann 1974, 382).

The precondition for a name must still be that it carries a sufficient number of identifying descriptions agreed upon by a sufficient number of name users (Vonen 1986, 67). It is also reason to believe that the meaning of a name depend on the context, differing from one individual to another and from one social group to another. A place name not only points out a place, it also mediates a cluster of qualities and meanings attached to that place, partly valid for a single individual, partly shared by a given social group. "Place-names do refer ...[but] they are used and valued for other reasons as well" (Basso 1984, 26). If a person has had positive experiences with a named place, then the name will tend to awake positive connotations, and conversely negative connotations will tend to emerge if he or she has had negative experiences with a place. I agree with Christopher Tilley when he posits that "place names are of such vital significance because they act so as to transform the sheer physical and geographical into something that is historically and socially experienced" (Tilley 1994,18). Everybody over a certain age who has spent sufficient time in the village of Lofthus in western Norway will identify the hill of Børvehovden (see picture) when the name is mentioned. Certainly not all of these will associate its name with the farm Børve behind the hill or with its function as a former defensive site or a place for the Midsummer's Eve bonfire, but some would more or less be able to make this association, depending on their linguistic experiences and on the contextual situation. Another example from this 


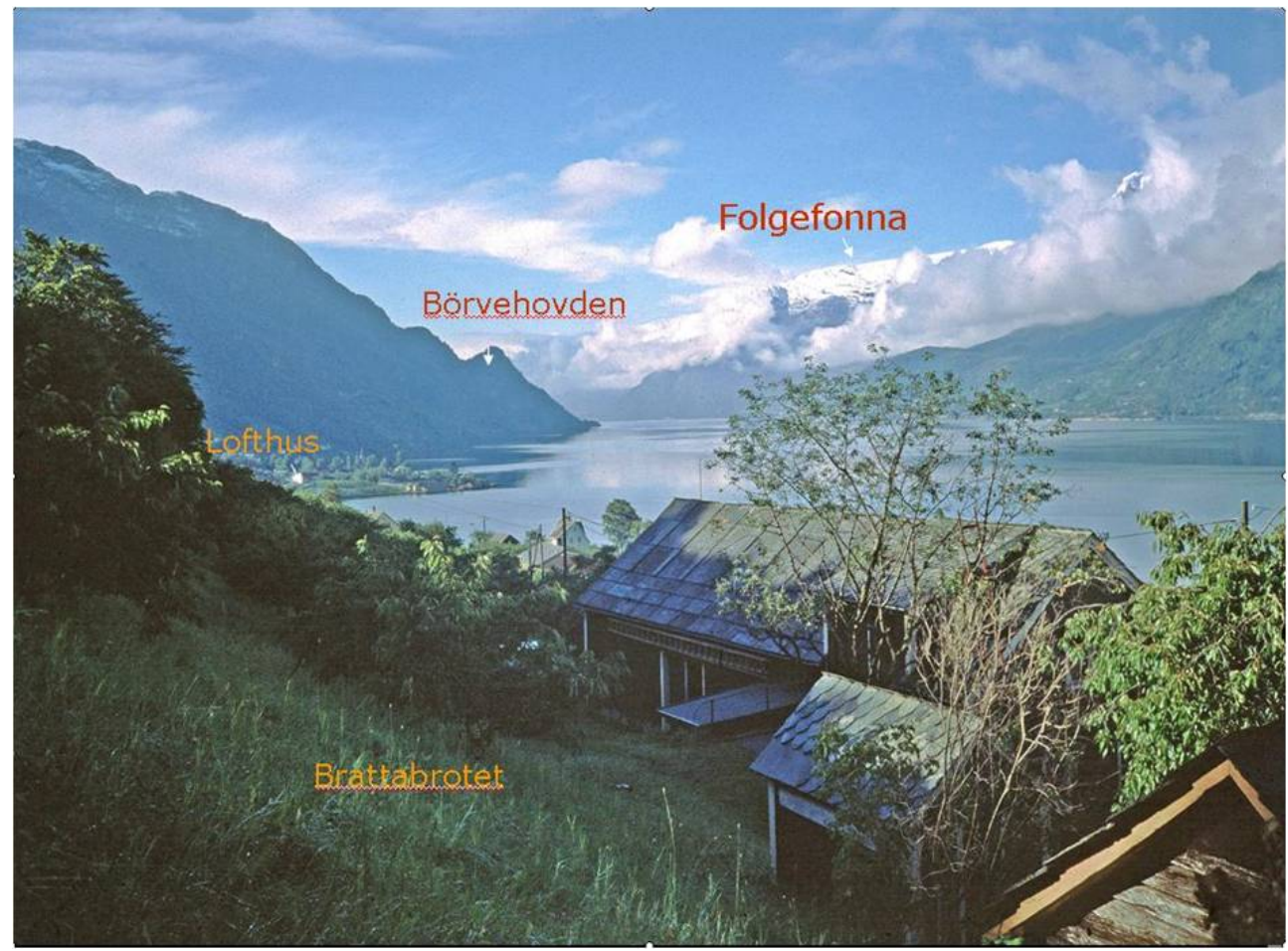

FIGURE 2: The farm Helland in Lofthus. In the background the hill Børvehovden and the Folgefonna glacier. In the foreground the field of Brattabrotet. Photo: B. Helleland.

setting is the field name Brattabrotet "the steep slope" on the small farm of Helland. This name is known only by the family occupying the farm and is associated with the difficulty of mowing and harvesting this field due to its steepness. For me and my brothers the name also carries memories of sledging on sunny winter days in our childhood.

\section{[3] PLACE NAMES - A LINK TO THE PAST}

Place names may be said to represent the oldest living part of human cultural heritage, in the sense that they have been handed down orally from generation to generation for hundreds or thousands of years at the place where they were coined. They are a special part of our cultural heritage in that they tell us something about the place to which they refer and about the name givers. Thus they provide important supplements to the history of the places where people settled, as ties to the past. Many place names are also identified with past events and are pegs upon which stories both written and oral can be hung. One can also see 
geographical names as a reflection of the interplay between humans and nature through different periods of time. Besides, if a person has some meta-linguistic and historic awareness, he may listen to place names as voices of the past, which in its turn may strengthen his feeling of home. Thus place names can function as a textual representation, often in an obsolete language, of the historic landscape.

When one takes into account that many place names have been coined as descriptions of the area or place in question, it becomes evident that we are dealing with material of immense historic value. Place names are links to the past, mirrors reflecting various scenarios and activities of the past. More recent names like names of dwelling places, streets, and fields and other microtoponyms also form a part of our collective onomastic memory and heritage. Although many people do not seem to be particularly aware of the historical richness of the place names in their surroundings they may still feel that the name stock contributes to their rootedness. People who have become acquainted with the etymological contents of names will of course appreciate their historical value to a greater degree. Through the place names of a district small or large, in particular its settlement names, it is possible to read many details of the area's history. A way of elucidating the historical contents of place names is shown in Figure 3.

At the top of the drawing in Figure 3 samples of existing place names are shown, each dating back a certain distance into the past. The suggested period of coinage is based on written sources and typological characteristics of the names and of the named places. The vertical lines, moving upwards, follow the passage of time. New names may be coined at any time, as old names sometimes fall out of use and become obsolete. The places to which the names refer are also constantly changing, sometimes unnoticeably, sometimes noticeably, but they may still be considered to be the same place.

If we look at the names mentioned in Figure 3, it is clear that their referents are something else today than they were in the past. Legene on the left is, for instance, used for a settlement which is only a couple of decades old. The etymological meaning of this name is "the place where the cattle rest", and that is what the name most probably referred to when it was coined. The name is not testified in writing before the $19^{\text {th }}$ century, but it is no doubt much older. Brekke, reflecting Old Norse brekka f. "slope, steep road" is now used in reference to a farm. It is recorded in the $14^{\text {th }}$ century, but the importance of the name and its onomastic typology indicate that it could be several hundred years older. The last example I will mention is Ullensvang on the far right of the drawing, the name of a parish and the farm on which the parish church was built (see also the picture and map below). It is recorded many times in the $13^{\text {th }}$ and $14^{\text {th }}$ centuries. As the name is apparently composed of the pagan god's name Ullin and vang "meadow where people assemble', there is reason to believe that it was coined in the centuries before the introduction of Christianity in Norway around the year 1000. Today - as 


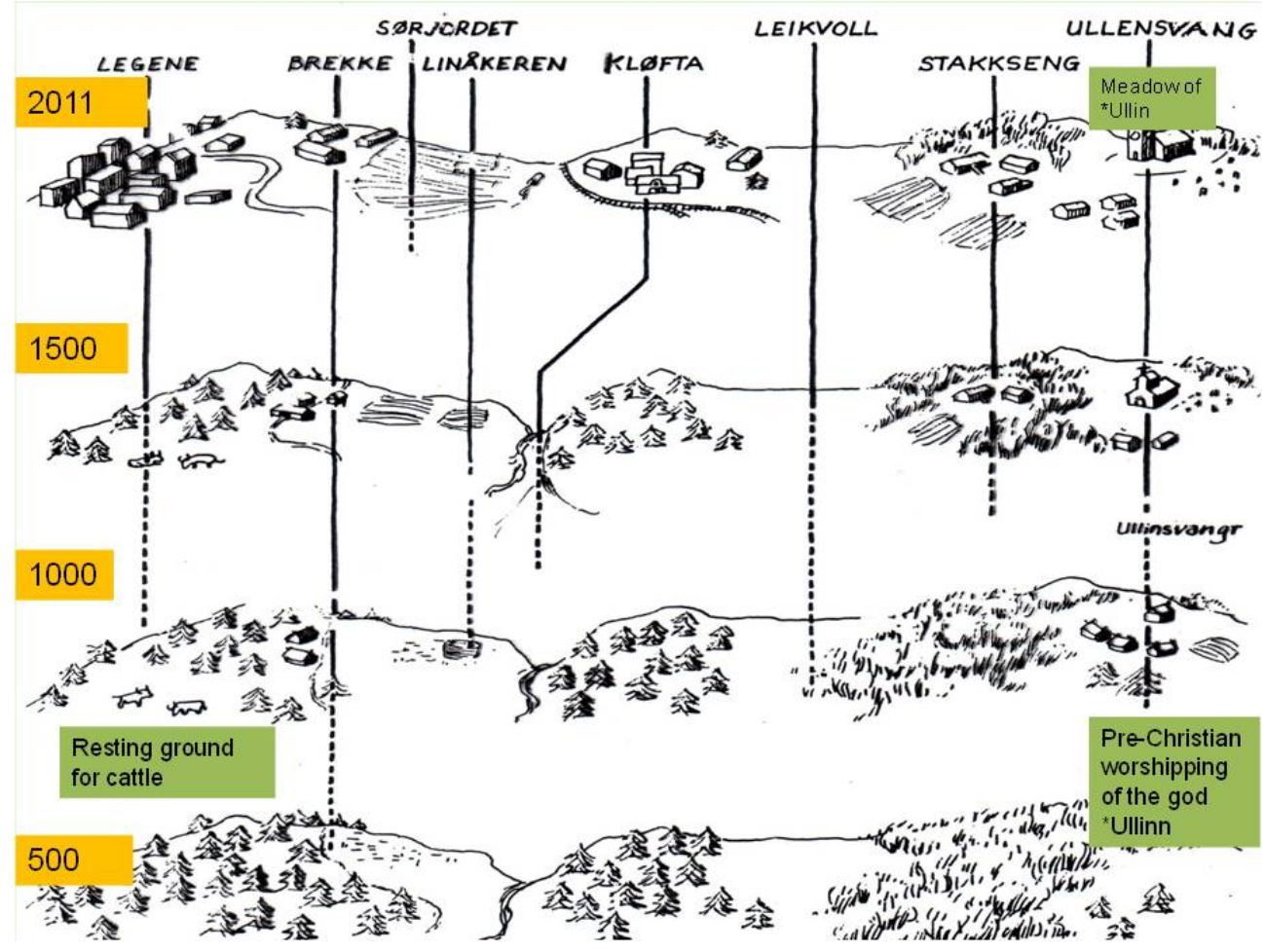

FIGURE 3: A named historical landscape as imagined at various periods of time. Drawing: B. Helleland.

probably a millennium ago - people use the name without thinking of its heathen background.

A representative expression of the viewpoints of communities of name scholars in this field is to be found in a report that came out of a symposium on place name care and planning held in Finland in 1977:

Place names are an important part of our geographical and cultural environment. They identify localities of different kinds and represent irreplaceable cultural values of vital significance to people's sense of belonging and well-being (Zilliacus 1978, 211). ${ }^{4}$

Place names function as a social consensus or a sort of an agreement reached over many generations. This quality, I feel, is another contribution to the wellbeing and ease of people who are familiar with the area and its names, although

[4] “Ortnamn är en viktig del av vår geografiska och kulturella miljö. De identifierar lokaliteter av olika slag och representerar oersättliga kulturella värden med avgörande betydelse för människors hemkänsla och trivsel." 
the name users may not be very conscious of it. Orally the place names of a local area are mostly used in a dialectal form, at least in Norway, which also reflects a social consensus. When local people see place names written on road signs and on maps they often react negatively because they feel that the standardized written forms of the names break with their idea of the correct name. This conflict, which sometimes makes the standardization of place names problematic, is an issue which needs to be discussed in relation to the preservation of place names as an intangible part of cultural heritage. This lies, however, outside the scope of this paper.

In 1999, Finland chose "Place Names - The Memory of Places" as theme for its European Heritage Days. The aim of Heritage Days is to awaken people to see and evaluate the environment built around them, and to help them appreciate its beauty and variety. Place names constitute an indispensable part of the environment, and the aim of Finland's 1999 Heritage Days was to make people aware of the use of such names in the planning process. The Heritage Days activity was used as a means of educating the public about the importance of standardizing geographical names without losing their historical value. During that year a number of events took place, with many people involved, and the organizers had good reason to call the arrangements a success. As part of these activities, a video was prepared by the Research Institute for the Languages of Finland, which was shown on Finnish television. ${ }^{5}$

\section{[4] SHARING OF PLACE NAMES}

Every speaker or group of speakers has at his or her disposal a certain number of place names (onomasticon) which constitute a referential system for the speaker(s) in question. Some names are known only by a small group of people, for instance those living in a single settlement, while others are known by people in a town or a district, and again others are known by people in a greater society. The Norwegian name scholar Magnus Olsen (Olsen 1939, 9 ff.), pointed long ago to the stratification of place names based on user groups. He suggested three levels: A) the names used within a single farm or village, B) the names used within a parish or municipality/local area, and C) the names used by those who travel long distances or have a bigger overview. Whereas the knowledge of names belonging to level A) is mostly limited to the locals, the names on level B) and in particular on level C) are also known to those on lower levels. The range of the place name

[5] "Place Names - The Memory of Places. The theme of the European Heritage Days in Finland 1999". UNGEGN, 20th Session, New York, 17 - 28 January 2000, Working Paper No. 22, submitted by Sirkka Paikkala, Finland. See also Sirkka Paikkala: "Place names in Finland as cultural heritage" in Onoma 35, 2000, pp. 145-164. 


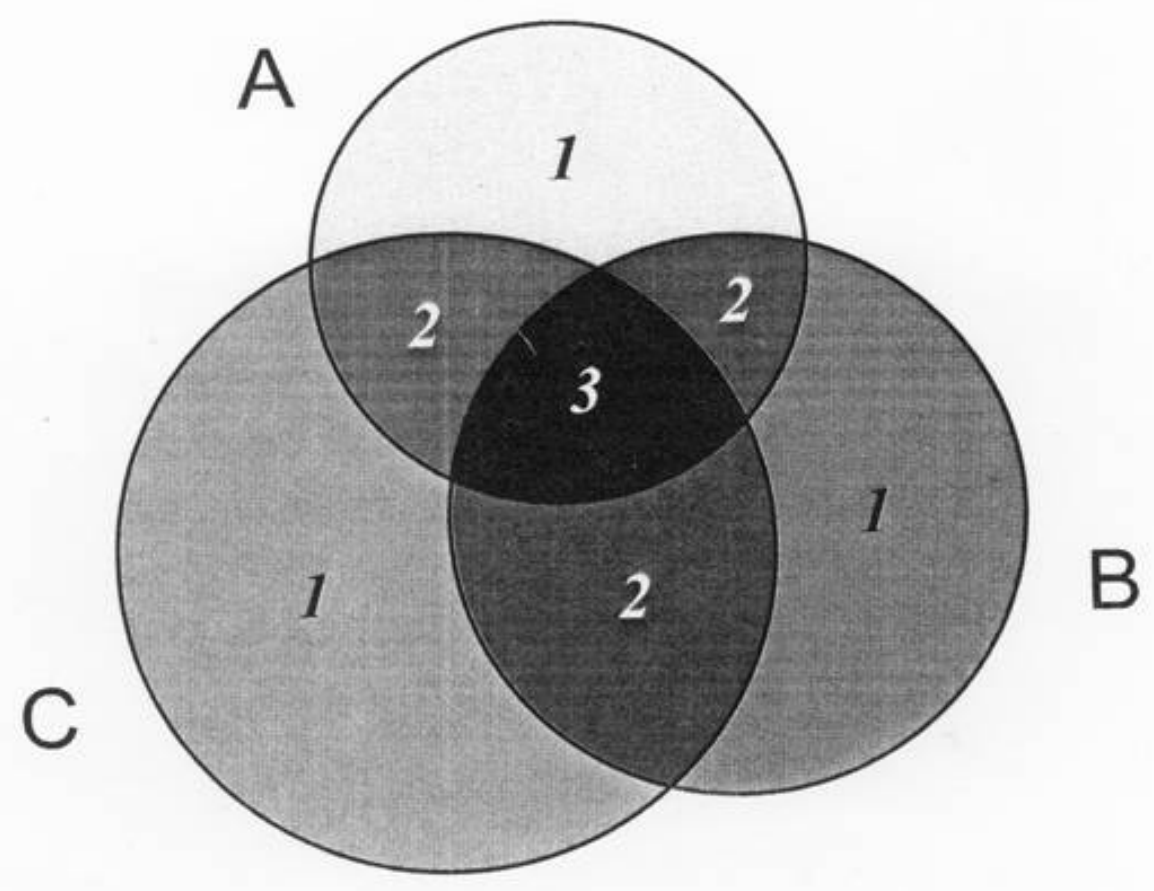

FIGURE 4: Sharing of place names.

competence of various name users may be illustrated by the model on the next page (Helleland 2006, 124).

In Figure 4, each of the three circles A, B, and C represents a name user or a name user's onomasticon. The sections marked $\mathbf{1}$ in each circle cover names which are known only by the single name user in question. The sections marked 2 cover names that one name user shares with another name user, for instance $\mathbf{A}$ with $\mathbf{B}$ or $\mathbf{B}$ with $\mathbf{C}$. The section marked $\mathbf{3}$ covers names which are known and used by all three name users. On the basis of this simplified model it is possible to imagine innumerable circles and sections to define the degree of shared place name competence of various social, geographical, linguistic, or other groups.

\section{[5] IDENTITY}

It is scarcely controversial to maintain that there is an intimate relationship between a person's self and her or his name, and other names to which the person may feel attached, including place names, and that such a mental relationship may be described as identity. Nevertheless identity is a complex and vague con- 
cept which is used in various meanings and contexts, such as personal identity, ethnic identity, place identity and so forth. The word identity goes back to Middle French identité, from Late Latin identitat-, identitas, probably from Latin identidem "repeatedly", contraction of idem et idem, literally "same and same" (MerriamWebster Online Dictionary). ${ }^{6}$ The Oxford English Dictionary (OED) defines identity as 1) "The quality or condition of being the same in substance, composition, nature, properties, or in particular qualities under consideration; absolute or essential sameness; oneness;" 2) "The sameness of a person or thing at all times or in all circumstances; the condition or fact that a person or thing is itself and not something else; individuality, personality." In his discussion of identity, Otto Krogseth (Krogseth 1992, 100-103), singles out continuity, coherence, and individuality as key elements, and all these may be represented when speaking about names and identity. For Jacobson-Widding (Jacobson-Widding 1998, 157), identity means two things, "sameness/continuity" and "distinctiveness/uniqueness".

We see that the term identity is used about stable and permanent conditions as well as processes; that which is embraced by identity often changes over time according to external circumstances and according to the mood and current state of mind of individuals or group of individuals. The identity concept of one generation may not be the same for the next generation (Hagström 2006, 19, 21). Many people who have lived in a city like Oslo since they moved there decades ago will often maintain bonds to their original home place, like the lady in the introduction above. However, Solveig Wikstrøm has shown that younger people living in Oslo who have farm names as surnames are, in emotional terms, more closely attached to their family through their surname than to the homestead from which their names are derived (Wikstrøm 2009).

Some of the scholars who are often cited with regard to the modern individual's self-understanding, are Anthony Giddens and Pierre Bourdieu. The first one posits that the modern individual is to a great extent independent of tradition, and the name plays an important role in the shaping of self-identity (Giddens $1996,71)$. The second sets out to demonstrate how social structures curtail the choices of the individual. He defines the name as a kinship status with a symbolic capital (Bourdieu 2000,54). Both theories imply that the individual has to shape her or his own identity. The linguist Brit Mæhlum claims that there is an opposition between personal and social identity and explains this double quality by positing that the identity of an individual becomes crystallized in the crosscurrents of the individual and the collective spheres (Mæhlum 2008, 108).

[6] http://www.merriam-webster. com/dictionary/identity?show=0\&t=1322499383. 
[6] SPACE AND PLACE

When talking about place names and identities it is also necessary to see place in relation to space. The two terms are interrelated but should be used separately as is common in, for instance, geography and anthropology. Space may be defined as "[s] uperficial extent or area; also, extent in three dimensions"; "extent or area sufficient for some purpose; room" (OED), whereas place may be defined as "[a] particular part of space, of defined or undefined extent, but of definite situation"; "[t]he portion of space actually occupied by a person or thing; the position of a body in space, or with reference to other bodies; locality, situation". One way of separating place from space is to name it: applying a name to a piece of space means creating a place. One of the frequently cited scholars regarding humans' adaptation to nature is Claude Lévi-Strauss, who defines space as "[a] society of named places, just as people are landmarks within the group. Places and individuals are designated by proper names, which can be substituted for each other in many circumstances common to many societies" (Lévi-Strauss 1966, 168). Yi-Fu Tuan puts it this way: "What begins as undifferentiated space becomes place as we get to know it better and endow it with value" (Tuan 1979, 6), "it is an object in which one can dwell" (op. cit., 12), or simply "localities on the surface of the earth" (Basso 1996, 89, note 10). Christopher Tilley suggests the following distinction between place and space in an identity perspective:

Personal and cultural identity is bound up with place; a topo-analysis is one exploring the creation of self-identity through place. Geographical experience begins in places, reaches out to others through spaces, and creates landscapes or regions for human existence (Tilley 1994, 15).

Still it is not so easy to delimit a "place", "as there can be a range of different ways in which specific places are represented" (Holloway \& Hubbard 2001, 144). Many places are defined according to their particular function, for instance properties and streets, but many others are features with unclear boundaries. Nevertheless they are felt as places as soon as they are brought into mind and become an object of interest.

\section{[7] PLACE ATTACHMENT AND PLACE IDENTITY}

The question of place attachment and place identity has become a popular topic in cultural geography and environmental psychology over the last couple of decades (Altman \& Low 1992; Lewicka 2008, 2010). Place attachment may be defined as an affective bond that people establish with specific areas where they prefer to remain and where they feel comfortable and safe (Hidalgo \& Hernández 2001, $273 \mathrm{f}$., Lewicka 2008, 211). Place identity may be said to encompass an individual's per- 
sonal identity in relation to the physical environment (Proshansky 1978, 147). It is therefore a component of personal identity, a process by which, through interaction with places, people describe themselves in terms of belonging to a specific place (Hernández 2007, 310), thereby creating "the source of meaning for a given setting by virtue of relevant cognitive clusters that indicate what should happen in it, what the setting is supposed to be like, and how the individual and others are supposed to behave in it" (Proshansky et al. 1983, 67).

There are several ways of studying humans' mental relationships with their surroundings, here more precisely with place, and there seem to be different approaches according to definition of place (Godkin 1980, 73). Laura Kostanski (Kostanski 2009, 65) suggests a stratification in which sense of place is an umbrella comprising place attachment, which in turn embraces place dependence and place identity, with this latter pair each slightly overlapping each other. These nuances are very fine and difficult to extract, but they may be useful when examining place name dependence and place name identity.

The term landscape is also frequently used when describing humans' physical surroundings. The relationship between humankind and landscape has been, and remains, a major topic for research. The simplest way of defining a landscape could be, in the words of J. B. Jackson (Jackson 1986, 67), "a collection of land", the arrangement of various natural and agricultural features. Christopher Tilley describes landscape, almost poetically, as "an anonymous sculptural form always already fashioned by human agency, never complete, and constantly being added to" (Tilley 1994, 23). But he also argues that landscapes, as well as places, are created by names (op. cit., 19). Sometimes the term mental landscape is used to describe different kinds of feelings which a landscape evokes in a person. Within environmental psychology there has been a shift in focus from here-and-now perception to how we think about landscape (Craik 1986, $51 \mathrm{f}$.). It is hardly controversial to maintain that a person's mental bond to a landscape is stronger when it is a familiar landscape than when it is a less familiar or unknown landscape. The term memorial landscape is used by some geographers (Dywer \& Alderman 2008) when examining the landscape as a text based on geographical and cultural processes. As more and more people live in urban areas there is now an increasing focus on the role of collective memory in urban space (Rose-Redwood et al. 2008), as well as on the role of urban place names as group building identity (Pounonen et al. 2009). Landscape identity may thus (in my context) be defined as "oneness between self and landscape as experienced by human beings in given circumstances". I would argue that a person's landscape identity (or place identity) is strengthened if he or she knows the place names of the area, or at least some of them. 


\section{[8] PLACE NAMES AND IDENTITIES}

When performing an Internet search for a combination of "identity" and "place name", millions of hits are returned, which shows that those terms are widely perceived as related. Both in scientific publications as well as in more popular literature, the role of place names as identity markers often comes to the surface. We see that the term "identity" is connected to personal names as well as place names and, as indicated above, it is used with a variety of meanings. When a person or a group of people feel a sort of identity through a name, it is not used in the same sense as when names are claimed to be markers of national, regional, or local identity.

Names are not only linguistic expressions referring to an object in the real or imagined world; they are also symbols that bring about a variety of feelings depending on the relationship between the name user(s) and the named object or person. Names are an important part of an individual's language and personal vocabulary, and as such of that individual's own self. So not surprisingly, personal names, place names and other names are increasingly being approached from a cognitive and mental point of view. Place names contribute to the feeling of belonging to an area and to a social group within that particular area. Whether people grow up and live in rural or in urban landscapes, they become familiar with their surroundings at an early stage and establish bonds to places. If they move and make their homes elsewhere they gradually also become acquainted with that area and its own place names. It is certainly possible to feel attached to a place without knowing the place names of the area or bearing them in mind, ${ }^{7}$ but as I see it, place names are abstractions of the places they refer to, substituting physical features with a wide range of impressions; they open up for a broader and more intimate knowledge of places. As has been demonstrated above, place names constitute links between name users and the named objects, as well as with the past.

What does it mean that a place or a place name creates a feeling of identity, and how are "place" and "place name" interrelated? When thinking of a named place, what comes first into mind, the place or its name, or do they appear simultaneously? To some extent, it is a "chicken-and-egg" dilemma, but it is still of some interest when approaching the relationship between place and place name. One of the most important contributions to the discussion of place names and identities in recent years is Laura Kostanski's doctoral thesis on the Grampians (Gariwerd) National Park name restoration process in Victoria, Australia (Kostanski 2009). Another important recent publication about the implications of naming

[7] Per Thomas Andersen (Andersen 2006) uses the term Identitetens geografi [The geography of identity] to express the bonds to a place in a literary context. 
for social identity is Critical Toponymies: The Contested Politics of Place Naming (Berg \& Vuolteenaho 2009).

James F. Weiner (Weiner 1991, 45) emphasizes that place names act "as mnemonics for the historical actions of humans that make places singular and significant". I agree with this view: without their place names it would indeed be more difficult to recall what happened at Verdun or Beaver Creek or any other named place. Keith H. Basso highlights the qualities of place names in the following way:

Because of their inseparable connection to specific localities, placenames may be used to summon forth an enormous range of mental and emotional associations - associations of time and space, of history and events, of persons and social activities, of oneself and stages in one's life (Basso 1990, 144).

Basso underlines the capacity and compact power of place names to evoke personal and cultural experiences. In his view, place names acquire a functional value "that easily matches their utility as instruments of reference" (ibid.). Certainly one of the qualities of place names lies in their ability to create a feeling of belonging to a certain community and feeling at home. But their symbolic function is important, too. In her thesis, Laura Kostanski examines if a person's attachment to a place is distinguishable from her or his attachment to the symbol of the place, i.e. the name, and on the basis of her research project she is able to conclude that this is the case (Kostanski 2009, 146). Her theory also includes that place name dependence ("toponymic dependence") exists as long as the place name provides a unique representation and people are dependent on a place for certain facilities. As I see it, the theoretical framework in Kostanski's thesis has contributed considerably to a better understanding of identity function of place names.

\section{[9] CONCLUSION - A PERSONAL EXPERIENCE}

Above I have introduced the landscape of my childhood, including some of the place names which I encountered at a very early age. I was once asked which place name I would regard as my favourite. Among the big stock of place names which mean something to me, Skutull is the one that counts the most. It is the name of a rock on the upper side of the farmhouses. When I was a little boy, I used to play there with the other boys and girls at my age, and we used to climb the rock to play Cowboys and Indians or to build stone huts. When I mention the name of Skutull to my playmates of that time they also express a certain amount of nostalgia. To some people Skutull means a happy childhood, surely mixed with fights and tears, with victories and defeats. To others it may mean a dwelling place with a nice view, a house with good or difficult neighbours and so on. The 


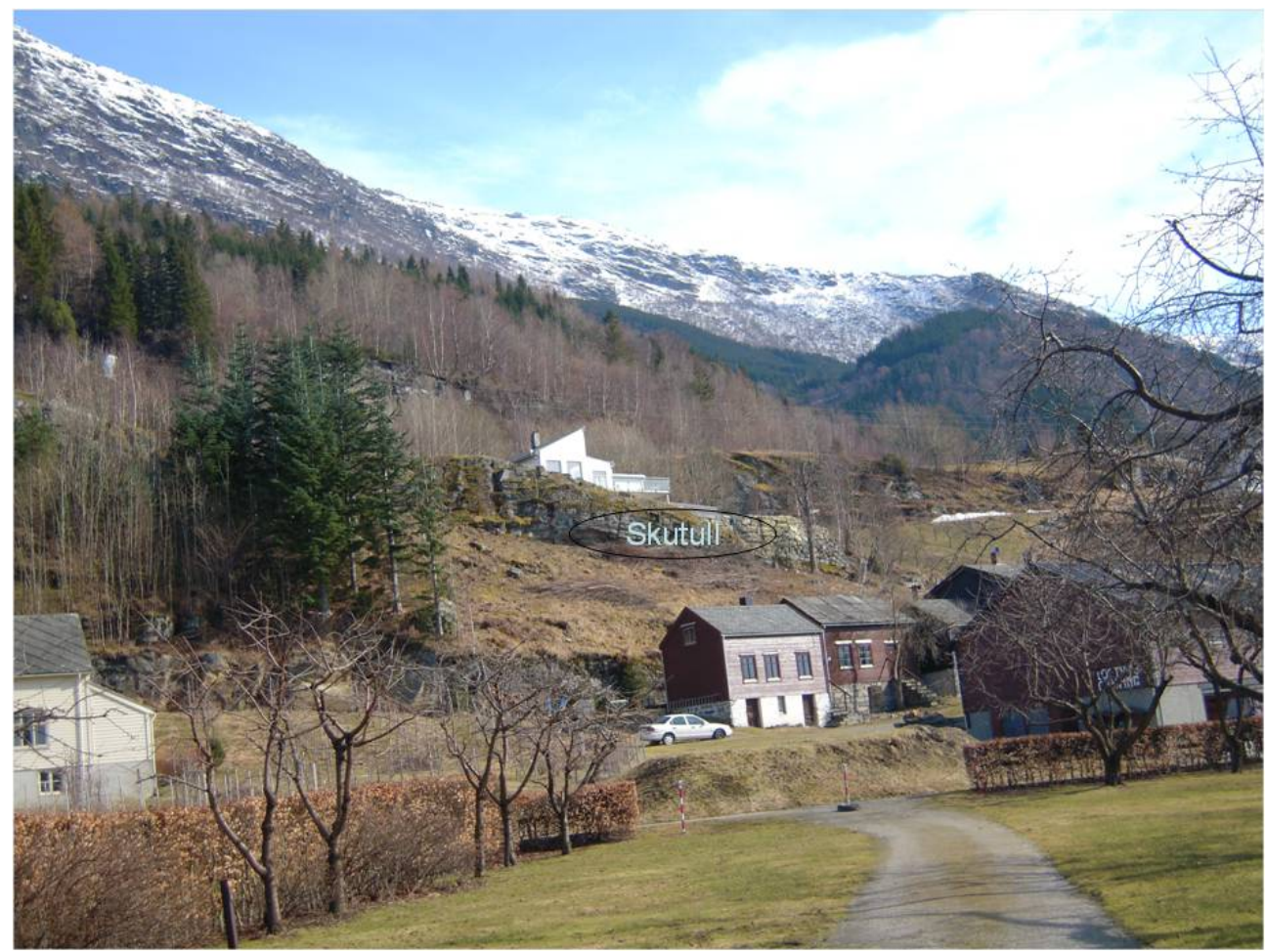

FIGURE 5: Skutull. Photo: B. Helleland.

name makes up part of the toponymic identity of the locals, evoking partly joint and partly individual experiences and feelings. So, as we get older and less capable of experiencing, the name of skutull is the gateway for visiting the place - in our minds.

\section{REFERENCES}

Altman, I. \& S.M. Low. 1992. Place Attachment. New York \& London: Plenum Press.

Andersen, P.T. 2006. Identitetens geografi. Steder i litteraturen fra Hamsun til Naipaul [The identity of geography. Places in the literature from Hamsun to Naipaul]. Oslo: Universitetsforlaget.

Andersson, T. 1994. Ortnamnens existentiella villkor [The existential conditions of place names]. In Ulfsparre, G. (ed.), Ortnamn värda att vårda. Föredrag från Riksantikvarieämbetets symposium Ortnamnskultur. Stockholm 5-7 maj 1993, 7-21. Stockholm: Riksantikvarieämbetet. 
Basso, K. 1984. "Stalking with stories": Names, places, and moral narratives among the Western Apache. In Plattner, S. \& E. M. Bruner (eds.), Text, Play, and Story: The Construction and Reconstruction of Self and Society. Proceedings of The American Ethnological Society. Washington: The American Ethnological Society.

Basso, K.H. 1990. Western Apache Language and Culture. Essays in Linguistic Anthropology. Tucson: The University of Arizona Press.

Basso, K.H. 1996. Wisdom sits in places: Notes on a Western Apache Landscape. In Feld, S. \& K.H. Basso (eds.): Sense of Place, 53-90. Santa Fe: School of American Research Press.

Berg, L.D. \& J. Vuolteenaho (eds.). 2009. Critical Toponymies: The Contested Politics of Place Naming. Farnham: Ashgate.

Bourdieu, P. 2000. Den maskuline dominans [Masculine dominance]. Oslo: Pax Forlag.

Christensen, V. \& J. Kousgård Sørensen. 1972. Stednavneforskning 1. Afgræensning. Terminologi. Metode. Datering [Place name research 1. Delimitation. Terminology. Methodology. Dating]. København: Universitetsforlaget.

Craik, K.H. 1986. Psychological reflections on landscape. In PenningRowsell, E.C. \& D. Lowenthal (eds.), Landscape Meanings and Values, 48-63. London-Boston-Sydney: Allen and Unwin.

Dywer, O.J. \& D.H. Alderman. 2008. Memorial landscapes: analytic questions and metaphors. GeoJournal 73. 165-178.

Eskeland, T. 2001. Stedsnavn og identitet [Place names and identity]. Nordlit 10. Available online: http://www.hum.uit.no/ nordlit/10/1eskeland.html.

Frege, G. 1962. Funktion, Begriff, Bedeutung. Göttingen: Vandenhoeck.

Gardiner, A.H. 1954. The Theory of Proper Names: A Controversial Essay. London: Oxford University Press. 2nd ed.

Gelling, M. 1990. The Historical Importance of English Place-names. In Boulanger, J.-C. (ed.), Proceedings of the XVIth International Congress of Onomastic Sciences. Québec, Université Laval 16-22 August 1987, 85-103. Québec: Les Presses de l'Université Laval.

Giddens, A. 1996. Modernitet og selvidentitet. Selvet og samfundet under senmoderniteten [Modernity and self-identity: self and society in late modern age]. København: Hans Reitzels Forlag. 
Godkin, M.A. 1980. Identity and place: clinical applications based on notions of the rootedness and uprootedness. In Buttimer, A. \& D. Seamon (eds.), The Human Experience of Space and Place. London: Croom Helm.

Hagström, C. 2006. Man är vad man heter. Namn och identitet [One is what one is named. Name and identity]. Stockholm: Carlssons.

Helleland, B. 1990. Flurnamen als lokalgeschichtliches Quellenmaterial. In Närhi, E. M. (ed.), Proceedings of the XVIIth International Congress of Onomastic Sciences, vol. 1, 415-422. Helsinki: The University of Helsinki and The Finnish Research Centre for Domestic Languages.

Helleland, B. 2006. The social and cultural values of geographical names. In Manual for the National Standardization of Geographical Names. United Nations Group of Experts on Geographical Names. (Department of Economic and Social Affairs, Statistics Division), 121-128. New York: United Nations.

Hernández, B. et al. 2007. Place attachment and place identity in natives and nonnatives. Environmental Psychology 27. 310-319.

Hidalgo, M.C. \& B. Hernández. 2001. Place attachment: Conceptual and empirical questions. Environmental Psychology 21. 273-281.

Hilgemann, K. 1974. Eigenname und semantische Strukturen. Beiträge zur Namenforschung. Neue Folge 9. 371-385. Also in Debus, F. \& W. Seibicke (eds.), Reader zur Namenkunde 1. Namentheorie. Hildesheim-Zürich-New York: Olms 1989. 21-40.

Holloway, L. \& P. Hubbard. 2001. People and place: the extraordinary geographies of everyday life. Pearson Education Limited.

Holmgren, S. et al. 2005. Det elektroniske kvarter. København: Socialministeriet. Available online: http://www.sm.dk/data/Lists/

Publikationer/Attachments/171/det_elektroniske_kvarter.pdf.

Huldén, L. 1994. Ortnamnens upplevelsevärde [The value of experiencing place names]. In Ulfsparre, G. (ed.), Ortnamn värda att vårda. Föredrag från Riksantikvarieämbetets symposium Ortnamns-

kultur. Stockholm 5-7 maj 1993, 32-37. Stockholm: Riksantikvarieämbetet.

Jackson, J.B. 1986. The Vernacular Landscape. In Penning-Rowsell, E. C. \& D. Lowenthal (eds.), Landscape Meanings and Values, 65-77. London-Boston-Sydney: Allen and Unwin. 
Jacobson-Widding, A. 1998. Att få en identitet utan namn. Släktskapstermernas betydelse för personlig identitet bland shonafolken i Zimbabwe [Getting an identity without a name. The significance of kinship terms for personal identity among the Shona population in Zimbabwe]. In Andersen, T., E. Brylla \& A. Jacobson-Widding (eds.). Personnamn och social identitet. Handlingar från ett Natur och Kultur-symposium i Sigtuna 19-22 september 1996. Konferenser 42. Kungl. Vitterhets Historie och Antikvitets Akademien, 157-177. Stockholm: Almqvist \& Wiksell.

Kostanski, L. 2009. What's in a Name? Place and Toponymic Attachment, Identity and Dependence. A case study of the Grampians (Gariwerd) National Park name restoration process. PhD. School of Business, University of Ballarat. Available online: http://archimedes.ballarat.edu.au:8080/vital/access/manager/ Repository/vital:2267.

Krogseth, O. 1992. Identitet [Identity]. In Henriksen, J.-0.\& O. Krogseth (eds.) in collaboration with P. K. Botvar \& I. T. Plesner, Pluralisme og identitet. Kulturanalytiske perspektiver på nordiske nasjonalkirker i møte med religiøs og moralsk pluralisme, 85-184. Oslo: Gyldendal Akademisk.

Lewicka, M. 2008. Place attachment, place identity, and place memory: Restoring the forgotten city past. Journal of Environmental Psychology 28. 209-231.

Lewicka, M. 2010. What makes neighborhood different from home and city? Effects of place scale on place attachment. Journal of Environmental Psychology 30. 35-51.

Lietz, G. 2009. Ideologisch motivierte Ortsnamenkonflikte im Mitteleuropa. Namn og Nemne 26. 57-92.

Light, D. 2004. Street names in Bucharest, 1990-1997: Exploring the modern historical geographies of post-socialist change. Journal of Historical Geography 30. 154-172.

Lévi-Strauss, C. 1966. The Savage Mind. Chicago: University of Chicago Press.

Mæhlum, B. 2008. Språk og identitet [Language and identity]. In Mchlum, B. et al. (eds.), Språkmøte. Innføring i sosiolingvistikk. 2nd ed., 106-119. Oslo: Cappelen akademisk forlag.

Mill, J.S. 1884. A System of Logic, Ratiocinative and Inductive: Being a Connected View of the Principles of Evidence and the Methods of Scientific Investigation. London: Longman. Reprint 1961.

Olsen, M. 1939. Norge [Norway]. In Olsen, M. (ed.), Stedsnavn. Nordisk kultur 5, 5-52. Oslo: Aschehoug. 
Pounonen, H., J. Vuolteenaho \& T. Ainiala. 2009. Industrial urbanization, workingclass lads and slang toponyms in early twentieth-century Helsinki. Urban History 36/03. 449-472.

Proshansky, H., A. Fabian \& R. Kaminoff. 1983. Place Identity: Physical World Socialisation of the Self. Journal of Environmental Psychology 3. 57-83.

Proshansky, H.M. 1978. The city and self-identity. Environment and Behavior 10. 147-169.

Rose-Redwood, R., D. Alderman \& M. Azaryahu. 2008. Collective memory and the politics of urban space: An introduction. GeoJournal 73. 161-164.

Russell, B. 1940. An Inquiry into Meaning and Truth. London: Allen and Unwin.

Rygh, O. 1919. Norske Gaardnavne 12. Nordre Bergenhus Amt [Norwegian Farm Names. Vol. 12. Nordre Bergenhus County]. Ed. by A. Kjæer. Kristiania: W.C. Fabritius \& Sønner.

Saparov, A. 2003. The alteration of place names and construction of national identity in Soviet Armenia. Cahiers du Monde russe 44/1. 179-198. Available online: http://monderusse.revues.org/docannexe4079.html.

Searle, J.R. 1969. Speech Acts: An Essay in the Philosophy of Language. Cambridge: Cambridge University Press. Also in Steinberg, J. R. \& L. A. Jakobvits (eds.): Semantics. An Interdisciplinary Reader in Philosophy, Linguistics and Psychology. Cambridge: Cambridge University Press. 1971.

Tilley, C. 1994. A Phenomenology of Landscape. Places, Paths and Monuments. OxfordProvidence, USA: Berg.

Tuan, Y.F. 1979. Space and Place: The Perspective of Experience. Minneapolis: University of Minnesota Press.

Van Langendonck, W. 2007. Theory and Typology of Proper Names. Berlin-New York: Mouton de Gruyter.

Viljamaa-Laakso, M. 1998. Urban names and identity. In Nicolaisen, W. F. H. (ed.), Proceedings of the XIXth International Congress of Onomastic Sciences. Aberdeen, August 4-11, 1996, vol. 2, 364-369. Aberdeen: Department of English, University of Aberdeen.

Vonen, A.M. 1986. Semantisk analyse av egennavn - noen sentrale problemstillinger [Semantic analysis of proper names: Some important approaches]. In Norskrift. Arbeidsskrift for nordisk språk og litteratur, vol. 51, 55-76. Oslo: Institutt for språk og litteratur. Universitetet i Oslo. 
Weiner, J.F. 1991. The Empty Place: Poetry, Space, and being among the Foi of Papua New Guinea. Bloomington: Indiana University Press.

Wetås, Å. 2000. Namneskiftet Kristiania - Oslo [The name change Kristiania - Oslo]. Oslo: Novus.

Wikstrøm, S. 2009. Etternavn, tilknytning og identitet i det post-tradisjonelle samfunnet [Surname, attachment and identity in the post-traditional society]. Namn og Nemne 26. 93-110.

Ziegler, A. \& E. Windberger-Heidenkummer. 2011. Methoden der Namenforschung, Methodologie, Methodik und Praxis. Berlin: Akademie Verlag.

Zilliacus, K. (ed.). 1978. Ortnamnsvård och ortnamnsplanering. Handlingar från NORNA:s femte symposium på Hanaholmen 23-25.9.1977 [Place name care and place name planning. Proceedings from NORNA's Fifth Symposium in Hanaholmen 23-25.9.1977]. NORNA-rapporter 13.

Zook, M.A. 2000. The web of production: the economic geography of commercial Internet content production in the United States. In Environment and Planning A, vol. 32, 411-426. Available online: http://www.environmentandplanning.com/epa/fulltext/a32/a32124.pdf.

AUTHOR CONTACT INFORMATION

Botolv Helleland

University of Oslo

Department of Linguistics and Scandinavian Studies

Box 1011 Blindern

NO - 0315 Oslo

Norway

botolv.helleland@iln.uio.no 